\title{
Motor learning of mice lacking cerebellar Purkinje cells
}

\author{
M. Elena Porras-García ${ }^{1}$, Rocío Ruiz² ${ }^{2}$ Eva M. Pérez-Villegas ${ }^{2}$ and José Á. Armengol ${ }^{1 *}$ \\ División de Neurociencias, Departamento de Fisiología, Anatomía y Biología Celular, Área de Anatomía y Embriología Humana y Fisiología, Universidad Pablo de \\ Olavide, Seville, Spain \\ 2 y Fisiología, Universidad Pablo de Olavide, Seville, Spain
}

Edited by:

Salvador Martinez, University

Miguel Hernandez, Spain

Reviewed by:

Ferdinando Rossi, University of

Turin, Italy

Salvador Martinez, University

Miguel Hernandez, Spain

*Correspondence:

José Á. Armengol, División de

Neurociencias, Departamento de

Fisiología, Anatomía y Biología

Celular, Área de Anatomía y

Embriología Humana y Fisiología

Universidad Pablo de Olavide, Ctra.

de Utrera Km. 1, 41013 Seville,

Spain.

e-mail: jaarmbut@upo.es
The cerebellum plays a key role in the acquisition and execution of motor tasks whose physiological foundations were postulated on Purkinje cells' long-term depression (LTD). Numerous research efforts have been focused on understanding the cerebellum as a site of learning and/or memory storage. However, the controversy on which part of the cerebellum participates in motor learning, and how the process takes place, remains unsolved. In fact, it has been suggested that cerebellar cortex, deep cerebellar nuclei, and/or their combination with some brain structures other than the cerebellum are responsible for motor learning. Different experimental approaches have been used to tackle this question (cerebellar lesions, pharmacological agonist and/or antagonist of cerebellar neurotransmitters, virus tract tracings, etc.). One of these approaches is the study of spontaneous mutations affecting the cerebellar cortex and depriving it of its main input-output organizer (i.e., the Purkinje cell). In this review, we discuss the results obtained in our laboratory in motor learning of both Lurcher (LC/+) and tambaleante (tbl/tb/) mice as models of Purkinje-cell-devoid cerebellum.

Keywords: cerebellum, motor learning, Lurcher, tambaleante, Purkinje cells

\section{INTRODUCTION}

The cerebellum coordinates motor activities to be performed or already underway. In fact, cerebellar damage produces disturbance in movements and in body support. The relationship between cerebellum and motor learning was first suggested with the studies of Ramón y Cajal (1911), Dow and Moruzzi (1958), and Eccles et al. (1967). Dow and Moruzzi (1958) hypothesized that the cerebellum contributes to motor learning by determining how to perform accurate and correct movements. Thereafter, numerous studies have been devoted to analyzing the role of the cerebellum in perceptive and cognitive processes. Thus, the essential contribution of Marr, localizing the site of motor learning in the cerebellar cortex (Marr, 1969), and the later application of Marr's theory to the classical conditioning (Albus, 1971), whose physiological basis are directly related to long-term depression (LTD) mechanisms (Ito, 1989), defined the neuronal circuit involved in associative motor learning which remains accepted and discussed.

The anatomically highly refined organization of the cerebellum and its afferent/efferent pattern of projections from/to motor and premotor regions of cerebral cortex and spinal cord provides a paradigmatic substrate supporting its participation in motor behavior and learning (see Bernard et al., 2012). Furthermore, the analysis of the development of the cerebellar hemispheres and the expansion of the cerebral cortex in phylogeny also suggests the involvement of the cerebellum in cognitive functions (Leiner et al., 1986). The topography of the cerebellar cortex is closely related to deep cerebellar nuclei arrangement which also have different motor function according to the region of the cerebellum in which they are situated, and each nucleus controls a different aspect of the movement for the whole-body map (Thach et al., 1992; Thach, 1997).

Numerous studies have been performed in order to determine the role of the different cerebellar parts as a site of motor learning and/or memory storage. Among the authors who give a central role to the cerebellum, some point to the cerebellar cortex (Attwell et al., 2001; Chen et al., 1996), some to the deep cerebellar nuclei (Clark et al., 1992; Bracha et al., 2001), while others postulate the coordinated work of cerebellar and extra-cerebellar regions (Aou et al., 1992; Delgado-García and Gruart, 2002; Christian and Thompson, 2003; Koekkoek et al., 2003; Jiménez-Díaz et al., 2004; Porras-García et al., 2005, 2010; Sánchez-Campusano et al., 2007, 2009; Freeman and Steinmetz, 2011). Different experimental approaches, such as retrograde trace with virus (Morcuende et al., 2002), lesions, or pharmacological studies of cerebellar structures (Yeo et al., 1985a,b; Bracha et al., 1999; Christian and Thompson, 2003; Jiménez-Díaz et al., 2004), electrophysiological recordings from cerebellar cortex and nuclear neurons (Gruart et al., 2000; Porras-García et al., 2010), the study of cerebellar developmental disorders (Manto and Jissendi, 2012), and the use of mutant mice (Chen et al., 1996; Grüsser-Cornehls and Bäurle, 2001; Koekkoek et al., 2003, 2005; Porras-García et al., 2005, 2010), have been used to elucidate the function of the cerebellum. For this last approach, some mutations resulting in a total loss of Purkinje cells are very useful. Here, we summarize the results obtained in tambaleante and Lurcher mutant mice as models used for this purpose.

\section{LURCHER MUTATION}

The Lurcher mutation appeared spontaneously in 1954 in the mouse colony of the Medical Research Council Radiobiological 
Research Unit at Harwell, England. In 1960, Phillips described motor-coordination problems associated to the Lurcher mutation. He also reported that this mutation was semi-dominant and the gene was localized on chromosome 6 (Phillips, 1960). The Lurcher mutation is caused by mutation in the $\delta 2$ glutamate receptor (GluR $\delta 2$; Caddy and Biscoe, 1979; Zuo et al., 1997). GluR $\delta 2$ is predominantly expressed in both Purkinje cells and several hindbrain cells (Araki et al., 1993; Lomeli et al., 1993; Mayat et al., 1995; Takayama et al., 1995, 1996; Landsend et al., 1997). Homozygous Lurcher mice $(L c / L c)$ die after birth (P0) through a massive loss of mid- and hind-brain cells (Cheng and Heintz, 1997; Resibois et al., 1997). In contrast, the heterozygous Lurcher mouse $(L c /+)$ suffers cerebellar Purkinje cell death from the third and fourth day after birth (P3-P4) (Swisher and Wilson, 1977). From the 8th day after birth (P8), the Purkinje cell loss produces the degeneration of granule cells and olivary neurons (Caddy and Biscoe, 1979). Three months after birth, the $L c /+$ mouse has lost almost every Purkinje cell, some $90 \%$ of granule cells, and some $75 \%$ of the olivary neurons (Caddy and Biscoe, 1979; Wetts and Herrup, 1982; Heckroth and Eisenman, 1991; Norman et al., 1995; Wullner et al., 1995; Doughty et al., 2000).

Despite the motor problems that appeared in $L c /+$ mice in various motor tests performed (fall, rotarod, ladder, horizontal bar, eyeblink classical conditioning), they were able to learn new motor tasks, but the amplitude of the learned responses were significantly lower than in wild-type mice (Lalonde, 1994; Caston et al., 1995; Le Marec et al., 1997; Hilber and Caston, 2001; Porras-García et al., 2005) (Figure 1). However, the lesion of the interpositus nucleus prevented the generation of conditioned eyeblink responses in $L c /+$ and wild-type mice (Yeo et al., 1985a; Welsh and Harvey, 1989; Bracha et al., 1999; Jiménez-Díaz et al., 2004; Porras-García et al., 2010). Moreover, electrophysiological recordings of interpositus and red nuclei in Lurcher mice during the eyeblink classical conditioning suggest compensatory mechanisms in the absence of cerebellar cortex during performance of learned movements (Porras-García et al., 2010). These results suggest that deep cerebellar nuclear neurons (interpositus and dentate nuclei) may be involved more in the modulation and proper performance of ongoing conditioned responses than in their generation and/or initiation during learning processes (Gruart et al., 1997; Delgado-García and Gruart, 2002; JiménezDíaz et al., 2004).

\section{TAMBALEANTE MUTATION}

The tambaleante mutation $(t b l)$ is a recessive mutation that appeared spontaneously in a DW/J-Pas background at the Pasteur Institute (Paris, France). This mutation affects cerebellar Purkinje cells, leading to their disappearance (Wassef et al., 1987). In the homozygous tambaleante $(t b l / t b l)$ mutation, the degeneration of Purkinje cells begins from the second month of life-a date from which the Purkinje cell number decreases dramatically. When the $t b l / t b l$ mouse is 1 year old, fewer than $1 \%$ of the cerebellar Purkinje cells survive (Dusart et al., 2006) (Figure 2). The gene related to the mutation is Hercl, which expresses a protein involved in the growth and maintenance of the cerebellar cytoarchitecture. Moreover, there seems to be a relationship between the increased levels of the mutated protein HERC1 and the autophagic death of the Purkinje cells in the tambaleante mouse (Mashimo et al., 2009).

The tambaleante $(t b l / t b l)$ mutation develops an ataxic syndrome (Wassef et al., 1987; Rossi et al., 1995), with signs of tremor, unstable gait, and abnormal posture of hind limbs, similar to that in other mutated cerebella devoid of Purkinje cells (Table 1). However, the phenotype of the $t b l / t b l$ mouse and the regressive phenomena that will take place "en cascade" as in other Purkinje-cell-mutated cerebella (Sotelo and Changeux, 1974a; Caddy and Biscoe, 1979) are not completely understood. Thus, data are still not available as to whether the $t b l / t b l$ mutation could affect only cerebellar Purkinje cells or whether other cerebellar and extracerebellar neuronal cell populations would also be affected directly or indirectly by the mutation. Despite the lack of concrete data on the extent of the $t b l / t b l$ mutation, the late onset of complete Purkinje-cell degeneration with respect to other mutations (Table 1), once all cerebellar circuits have developed normally, makes it a perfect model for studying the cerebellar involvement in various motor learning tasks.

Recent studies carried out in our lab show that the $t b l / t b l$ mouse seems not to have its motor learning capabilities completely affected (Figure 1). Thus, although slower than wild-type mice, $t b l / t b l$ mice perform both fall and horizontal bar test successfully (Figures 1A,B), learning consistently from the first to last session. However, $t b l / t b l$ mice were unable to adapt their motor responses in the vertical pole test, in which they systematically failed to learn through the four sessions (Figure 1C).

Purkinje cell loss elicits a series of compensatory structural changes in the main cerebellar output (i.e., from deep cerebellar and vestibular nuclei). The diminution on Purkinje cell inhibitory input leads to changes in these neuronal populations that have been closely related to mutant behavioral phenotypes. Among these neural responses, an increase in the parvalbumin (Parv) was consistently found in cerebellar and vestibular nuclei after spontaneous or surgical Purkinje cell deprivation (Grüsser-Cornehls and Bäurle, 2001). In DW/J-Pas wild-type mice, deep cerebellar and vestibular nuclei neuronal somata are Parv- (Figure 2D), while small Parv+ terminal endings are present (Figure 2E). As in the $L c /+$ mutation (Grüsser-Cornehls and Bäurle, 2001), Parv+ somata are found through all deep cerebellar nuclei in $t b l / t b l$ mice (Figures 2F,G). Parv immunoreactivity of presynaptic boutons is also different in $t b l / t b l$ deep cerebellar nuclei, andtogether with small boutons (Figure 2I) - there is an increase in the presence of larger Parv+ endings (Figure 2H). Therefore, Parv immunoreactivity of $t b l / t b l$ mice is similar to that observed in other Purkinje-cell-deprived mutations, reinforcing the relationships between motor behavior and Parv expression in deep cerebellar and vestibular nuclei (Grüsser-Cornehls and Bäurle, 2001).

Despite the similarities in the structural changes suffered by the different Purkinje-cell-devoid mutant mice sharing a similar motor behavior (Table 1), there are subtle differences in the motor response of the two strains analyzed here. Thus, while no differences were found in the fall test (Figure 1A), $t b l / t b l$ mice seemed to perform the horizontal bar test more easily than did $L c /+$ ones (Figure 1B). In contrast, $t b l / t b l$ mice were consistently unable to successfully perform the vertical 
A

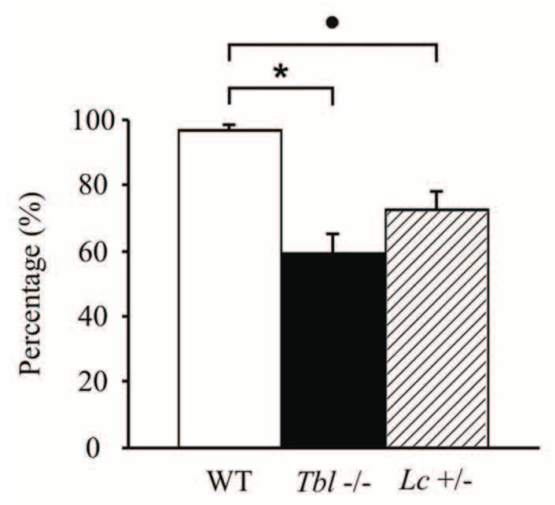

B

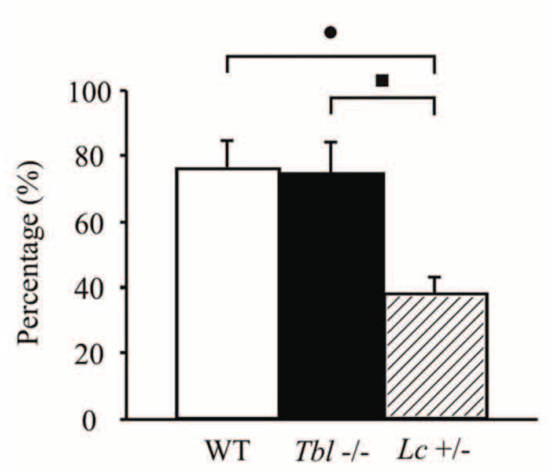

C
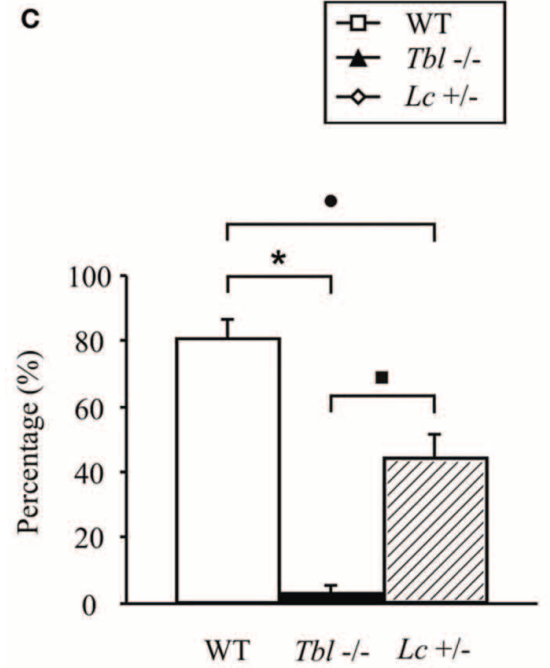

FIGURE 1 | Comparison of motor activity and motor learning in tambaleante (tbl-/-), Lurcher ( $L c /+$ ), and wild-type (WT) mice evaluated in various motor tasks: fall (A), horizontal bar (B), and vertical pole (C) performed twice a day during 4 days. Significant differences were found between groups in the percentage (\%) mean values (left) [One-Way ANOVA $F$-test, $F_{(6,1158)}=17.50$ (fall); $F_{(6,1158)}=8.45$ (horizontal bar); $F_{(6,1158)}=45.28$ (vertical pole), $P<0.05$ ] as well as in the temporal
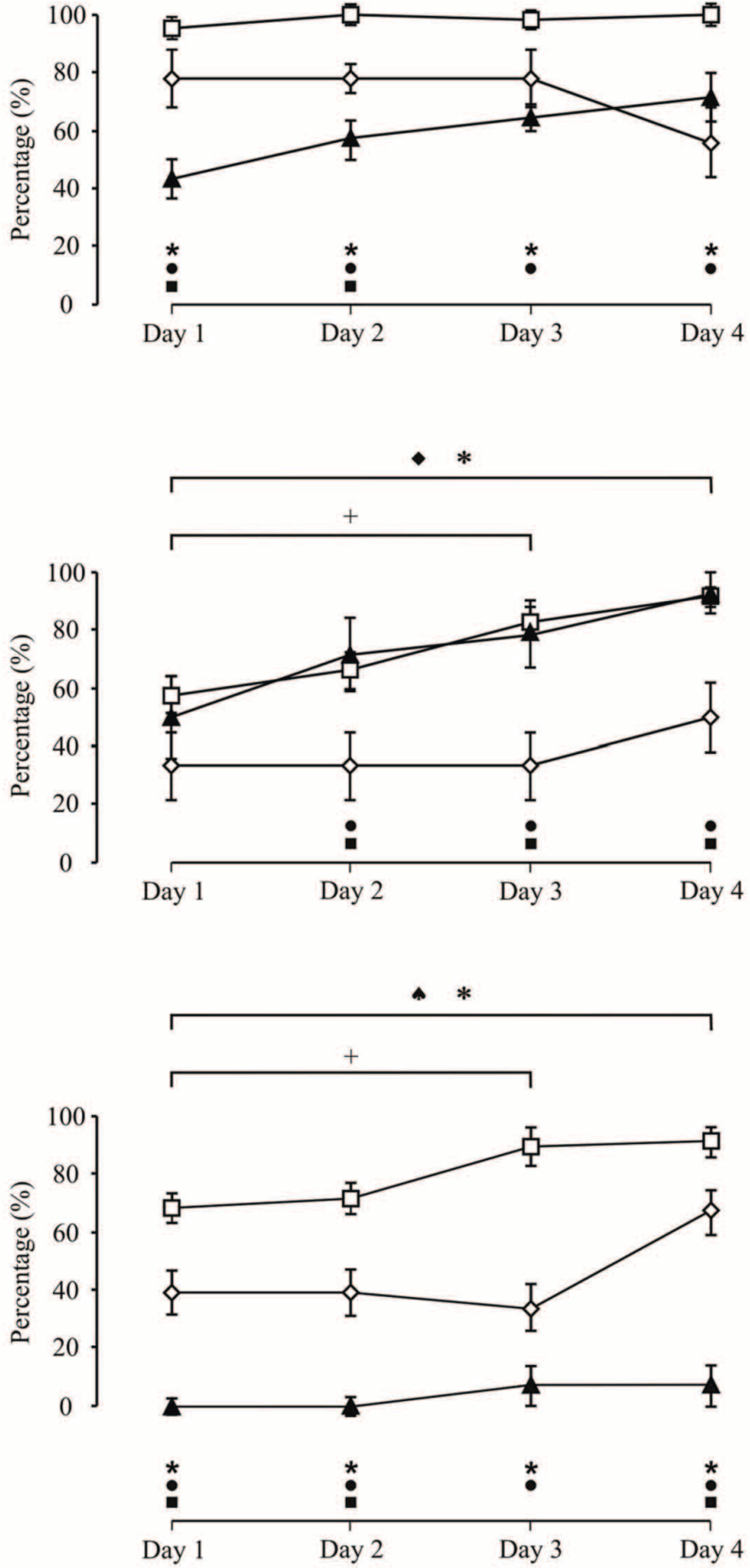

evolution for each of the tests (right). [Two-Way ANOVA F-test,

$F_{(4,360)}=2.41$ (fall); $F_{(4,360)}=0.56$ (horizontal bar); $F_{(4,360)}=1.62$ (vertical pole), $P<0.05]$. significant differences between tambaleante mice;

+ , between different sessions of wild-type animals; $\boldsymbol{\uparrow}$, between Lurcher mice; $*$, between tambaleante and wild-type mice; $\mathbf{\square}$, between tambaleante and Lurcher animals; and $\bullet$, between Lurcher and wild-type mice. Lurcher mice data collected from Porras-García et al. (2005). 


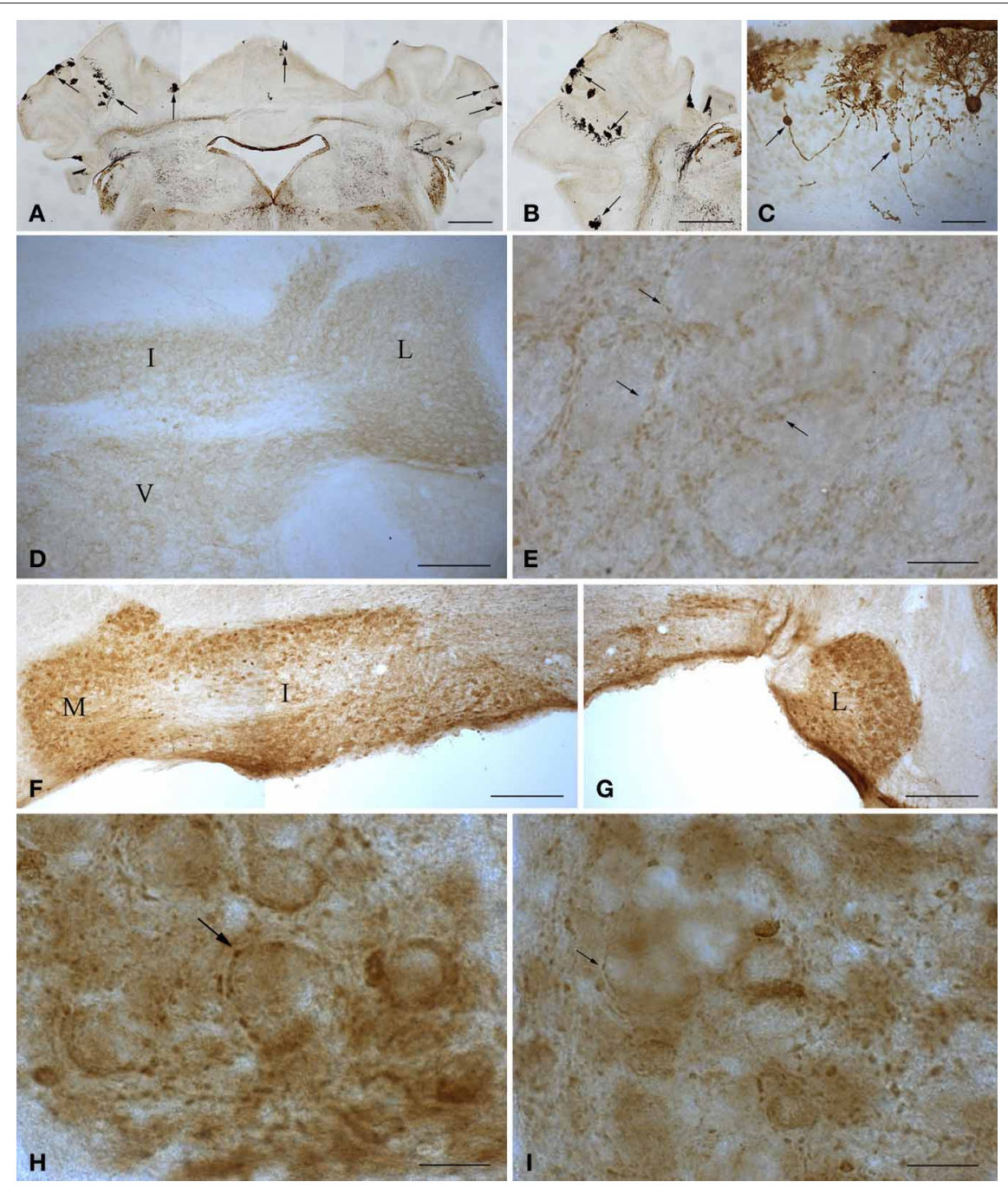

FIGURE 2 | Microphotographs of coronal (A, D-I) and sagittal (B,C) sections immunostained with anti-calbindin (A-C) and anti-parvalbumin (D-I) antibodies illustrate the main features of the cerebellum of wild type and 1-year-old tambaleante mice. Scarce Purkinje cells remain throughout the cortex (A-B, arrows), preserving a mirror location on both sides of the cerebellar cortex (A, arrows). Axons of degenerating Purkinje cells show typical axonal torpedoes ( $\mathbf{C}$, arrows). Parvalbumin immunoreactivity is restricted to small endings ( $\mathbf{E}$, arrows), and is absent in both deep cerebellar and vestibular nuclei neuronal somata (D), in wild-type cerebellum. In tambaleante cerebellum, parvalbumin immunoreactivity is

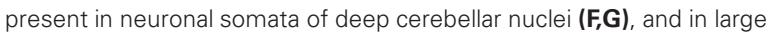
(H, arrow) and small (I, arrow) terminal endings. I, L, and $\mathbf{M}$, interposed, lateral, and medial cerebellar nuclei. , vestibular nuclei. Bar $=500 \mu \mathrm{m}(\mathbf{A}, \mathbf{B})$, $200 \mu \mathrm{m}$ (D,F,G), $30 \mu \mathrm{m}$ (C), and $20 \mu \mathrm{m}$ (E,H,I). pole test, while $L c /+$ mice did (Figure 1C). These differences in motor learning could be due to dissimilarities between the two mutant mice in the structural changes in cerebellar connectivity as the result of Purkinje cell loss. A possible explanation of these differences could reside in the different temporal onset of Purkinje-cell degeneration, as $t b l / t b l$ is the only mutation that losses all Purkinje cells once the cerebellar circuits have developed normally (Wassef et al., 1987; Rossi et al., 1995; Dusart et al., 2006) (Table 1). A detailed analysis of the $t b l / t b l$ cerebellum regarding the total amount of granule cells after Purkinje cell loss, and the cerebellar cortico-nuclear relationships at the beginning of the mutation effect, would explain these motor learning differences. Accordingly, the comparison of amounts of GABAergic input to cerebellar deep nuclei between $L c /+$ and $t b l / t b l$ mice could help to solve the question (see GrüsserCornehls and Bäurle, 2001). However, it is noteworthy that genes leading to Purkinje cell degeneration also affect other brain regions, and that ataxic symptoms and motor behavior are most severe in mutant mice whose brain is widely affected (Table 1). Hence, the analysis of $t b l / t b l$ brain areas involved in motor behavior and the possible compensatory processes taking place after the loss of Purkinje cells when all motor circuitry is fully developed would explain the differences in $t b l / t b l$ motor behavior.

\section{CONCLUSION}

Various studies give the cerebellar cortex an important role in motor learning. However, the results obtained in our laboratory, 
Porras-García et al.

Motor learning and mutant cerebella

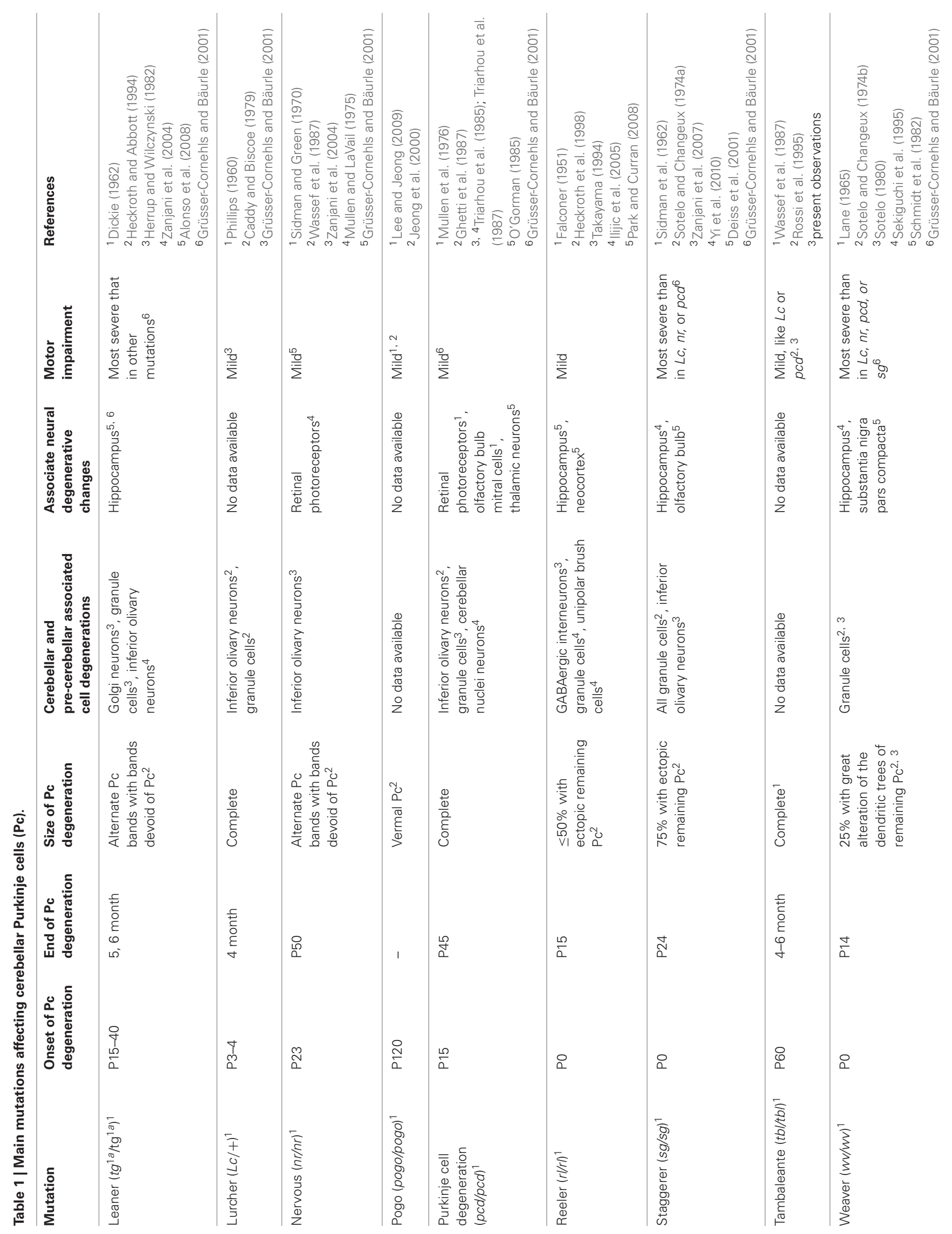

Frontiers in Neuroanatomy

www.frontiersin.org

April 2013 | Volume 7 | Article 4 | 5 
using two Purkinje-cell-deprived mutant mice, show that while this structure is not essential in learning, its absence disturbs the performance and the magnitude of the learned response (Porras-García et al., 2005, 2010). This is not so in the case of the interpositus nucleus of the cerebellum, in which any injury causes a total lack of learning (PorrasGarcía et al., 2010). In accord with our results and those of some other authors, it seems motor learning must be due to

\section{REFERENCES}

Albus, J. S. (1971). A theory of cerebellar function. Math. Biosci. 10, 25-61.

Alonso, I., Marques, J. M., Sousa, N., Sequeiros, J., Olsson, I. A., and Silveira, I. (2008). Motor and cognitive deficits in the heterozygous leaner mouse, a Cav2.1 voltagegated $\mathrm{Ca} 2+$ channel mutant. Neurobiol. Aging 29, 1733-1743.

Aou, S., Woody, C. D., and Birt, D. (1992). Changes in the activity of units of the cat motor cortex with rapid conditioning and extinction of a compound eye blink movement. J. Neurosci. 12, 549-559.

Araki, K., Meguro, H., Kushiya, E., Takayama, C., Inoue, Y., and Mishina, M. (1993). Selective expression of the glutamate receptor channel delta 2 subunit in cerebellar Purkinje cells. Biochem. Biophys. Res. Commun. 197, 1267-1276.

Attwell, P. J., Rahman, S., and Yeo, C. H. (2001). Acquisition of eyeblink conditioning is critically dependent on normal function in cerebellar cortical lobule HVI. J. Neurosci. 21, 5715-5722.

Bernard, J. A., Sleidler, R. D., Hassevoort, K. M., Benson, B. L., Welsh, R. C., Wiggins, J. L., et al. (2012). Resting state corticocerebellar functional connectivity networks: a comparison of anatomical and self-organizing map approaches. Front. Neuroanat. 6:31. doi: 10.3389/fnana.2012.00031

Bracha, V., Kolb, F. P., Irwin, K. B., and Bloedel, J. R. (1999). Inactivation of interposed nuclei in the cat: classically conditioned withdrawal reflexes, voluntary limb movements and the action primitive hypothesis. Exp. Brain Res. 126, 77-92.

Bracha, V., Zhao, L., Irwin, K. B., and Bloedel, J. R. (2001). Intermediate cerebellum and conditioned eyeblinks. Parallel involvement in eyeblinks and tonic eyelid closure. Exp. Brain Res. 136, 41-49.

Caddy, K. W., and Biscoe, T. J. (1979). Structural and quantitative studies on the normal $\mathrm{C} 3 \mathrm{H}$ and Lurcher mutant mouse. Philos. Trans. R. Soc. Lond. B Biol. Sci. 287, 167-201.

Caston, J., Vasseur, F., Stelz, T., Chianale, C., Delhaye-Bouchaud, N., and Mariani, J. (1995). Differential roles of cerebellar cortex and deep cerebellar nuclei in the learning of the equilibrium behavior: studies in intact and cerebellectomized lurcher mutant mice. Brain Res. Dev. Brain Res. 86, 311-316.

Chen, L., Bao, S., Lockard, J. M., Kim, J. K., and Thompson, R. F. (1996). Impaired classical eyeblink conditioning in cerebellarlesioned and Purkinje cell degeneration (pcd) mutant mice. J. Neurosci. 16, 2829-2838.

Cheng, S. S. W., and Heintz, N. (1997). Massive loss of mid- and hindbrain neurons during embryonic development of homozygous lurcher mice. J. Neurosci. 17, 2400-2407.

Christian, K. M., and Thompson, eyeblink conditioning: acquisition and retention. Learn. Mem. 10, 427-455.

Clark, R. E., Zhang, A. A., and Lavond, D. G. (1992). Reversible lesions of the cerebellar interpositus nucleus during acquisition and retention of a classically conditioned behavior. Behav. Neurosci. 106, 879-888. Strazielle, C. (2001). Cytochrome oxidase activity in the olfactory system of staggerer mutant mice. Brain Res. 910, 126-133.

Delgado-García, J. M., and Gruart, A. (2002). The role of interpositus nucleus in eyelid conditioned responses. Cerebellum 1, 289-308.

Dickie, M. (1962). A new viable yellow mutation in the house mouse (Intermediate agouti (A1)). Mouse News Lett. 23, 37.

Doughty, M. L., De Jager, P. L., Korsmeyer, S. J., and Heintz, N. (2000). Neurodegeneration in Lurcher mice occurs via multiple cell death pathways. J. Neurosci. 20, 3687-3694. R. F. (2003). Neural substrates of

Deiss, V., Dubois, M., Lalonde, R., and coordinated work between several cerebellar and extra-cerebellar structures.

\section{ACKNOWLEDGMENTS}

We are indebted to Dr. J. L. Rosa for his generous gift of tambaleante founders. We are also grateful to Dr. J. M. DelgadoGarcía for critical reading of the manuscript. José Á. Armengol is supported by a P07-CVI-2487 grant.

Dow, R. S., and Moruzzi, G. (1958). The Physiology and Pathology of the Cerebellum. Minneapolis, MN: University of Minnesota Press.

Dusart, I., Guenet, J. L., and Sotelo, C. (2006). Purkinje cell death: differences between developmental cell death and neurodegenerative death in mutant mice. Cerebellum 5, 163-173.

Eccles, J. C., Ito, M., and Szentágothai, J. (1967). The Cerebellum as a Neuronal Machine. Berlin: SpringerVerlag.

Falconer, D. S. (1951). 2 new mutants, trembler and reeler, with neurological actions in the house mouse (mus-musculus 1). J. Genet. 50, 192-201.

Freeman, J. H., and Steinmetz, A. B. (2011). Neural circuitry and plasticity mechanisms underlying delay eyeblink conditioning. Learn. Mem. 18, 666-677.

Ghetti, B., Norton, J., and Triarhou, J. C. (1987). Nerve cell atrophy and loss in the inferior olivary complex of "Purkinje cell degeneration" mutant mice. J. Comp. Neurol. 260, 409-422.

Gruart, A., Guillazo-Blanch, G., Fernández-Mas, R., JiménezDíaz, L., and Delgado-García, J. M. (2000). Cerebellar posterior interpositus nucleus as an enhancer of classically conditioned eyelid responses in alert cats. J. Neurophysiol. 84, 2680-2690.

Gruart, A., Pastor, A. M., Armengol, J. A., and Delgado-García, J. M. (1997). Involvement of cerebellar cortex and nuclei in the genesis and control of unconditioned and conditioned eyelid motor responses. Prog. Brain Res. 114, 511-542.

Grüsser-Cornehls, U., and Bäurle, J. (2001). Mutant mice as a model for cerebellar ataxia. Prog. Neurobiol. 63, 489-540.

Heckroth, J. A., and Abbott, L. C. (1994). Purkinje cell loss from alternating sagittal zones in the cerebellum of leaner mutant mice. Brain Res. 658, 93-104.

Heckroth, J. A., and Eisenman, L. M. (1991). Olivary morphology and olivocerebellar pathology in adult lurcher mutant mice. J. Comp. Neurol. 312, 641-651.

Heckroth, J. A., Goldowitz, D., and Eisenman, L. M. (1998). Purkinje cell reduction in the reeler mutant mouse: a quantitative immunohistochemical study. J. Comp. Neurol. 279, 546-555.

Herrup, K., and Wilczynski, S. L. (1982). Cerebellar cell degeneration in the leaner mutant mouse. Neuroscience 7, 2185-2196.

Hilber, P., and Caston, J. (2001). Motor skills and motor learning in Lurcher mutant mice during aging. Neuroscience 102, 615-623.

Ilijic, E., Guidotti, A., and Mugnaini, E. (2005). Moving up or moving down? Malpositioned cerebellar unipolar brush cells in reeler mouse. Neuroscience 136, 633-647.

Ito, M. (1989). Long term depression. Annu. Rev. Neurosci. 12, 85-102.

Jeong, Y. G., Hyun, B. H., and Hawkes, R. (2000). Abnormalities in cerebellar Purkinje cells in the novel ataxic mutant mouse, pogo. Dev. Brain Res. 125, 61-67.

Jiménez-Díaz, L., Navarro-López, Jde. D., Gruart, A., and Delgado-García, J. M. (2004). Role of cerebellar interpositus nucleus in the genesis and control of reflex and conditioned eyelid responses. J. Neurosci. 24, 9138-9145.

Koekkoek, S. K., Hulscher, H. C., Dortland, B. R., Hensbroek, R. A., Elgersma, Y., Ruigrok, T. J., et al. (2003). Cerebellar LTD and learning-dependent timing of conditioned eyelid responses. Science 301, 1736-1739.

Koekkoek, S. K., Yamaguchi, K., Milojkovic, B. A., Dortland, B. R., Ruigrok, T. J., Maex, R., et al. (2005). Deletion of FMR1 in Purkinje cells enhances parallel fiber LTD, enlarges spines, and attenuates cerebellar eyelid conditioning in Fragile $\mathrm{X}$ syndrome. Neuron 47, 339-352.

Lalonde, R. (1994). Motor learning in lurcher mutant mice. Physiol. Behav. 639, 351-353.

Landsend, A. S., Amiry-Moghaddam, M., Matsubara, A., Bergersen, L., 
Usami, S., Wenthold, R. J., et al. (1997). Differential localization of delta glutamate receptors in the rat cerebellum: coexpression with AMPA receptors in parallel fiber-spine synapses and absence from climbing fiberspine synapses. J. Neurosci. 17, 834-842.

Lane, P. W. (1965). "Weaver, wv, recessive," in Catalog of the Neurological Mutations of the Mouse, eds R. L. Sidman, M. C. Green, and S. H. Appel (Cambridge, MA: Harvard University Press), 66-67.

Lee, N. S., and Jeong, Y. G. (2009). Pogo: a novel spontaneous ataxic mutant mouse. Cerebellum 8, 155-162.

Leiner, H. C., Leiner, A. L., and Dow, R. S. (1986). Does the cerebellum contribute to mental skills? Behav. Neurosci. 100, 443-454.

Le Marec, N., Caston, J., and Lalonde, R. (1997). Impaired motor skills on static and mobile beams in lurcher mutant mice. Exp. Brain Res. 116, 131-138.

Lomeli, H., Sprengel, R., Laurie, D. J., Kohr, G., Herb, A., Seeburg, P. H., et al. (1993). The rat delta-1 and delta-2 subunits extend the excitatory amino acid receptor family. FEBS Lett. 315, 318-322.

Manto, M. U., and Jissendi, P. (2012). Cerebellum links between development, developmental disorders and motor learning. Front. Neuroanat. 6:1. doi: 103389/fnana.2012.00001

Marr, D. (1969). A theory of cerebellar cortex. J. Physiol. 202, 437-470.

Mashimo, T., Hadjebi, O., AmairPinedo, F., Tsurumi, T., Langa, F., Serikawa, T., et al. (2009). Progressive Purkinje cell degeneration in tambaleante mutant mice is a consequence of a missense mutation in HERC1 E3 Ubiquitin ligase. PLoS Genet. 5:e1000784. doi: 10.1371/journal.pgen.1000784

Mayat, E., Petralia, R. S., Wang, Y. X., and Wenthold, R. J. (1995). Immunoprecipitation, immunoblotting, and immunocytochemistry studies suggest that glutamate receptor delta subunits form novel postsynaptic receptor complexes. J. Neurosci. 3 , 2533-2546.

Morcuende, S., Delgado-García, J. M., and Ugolini, G. (2002). Neuronal premotor networks involved in eyelid responses: retrograde transneuronal tracing with rabies virus from the orbicularis oculi muscle in the rat. J. Neurosci. 22, 8808-8818.
Mullen, R. J., Eicher, E. M., and Sidman, R. L. (1976). Purkinje cell degeneration, a new neurological mutation in mouse. Proc. Natl. Acad. Sci. U.S.A. 73, 208-212.

Mullen, R. J., and LaVail, M. (1975). Two types of retinal degeneration in cerebellar mutant mice. Nature 258, 528-530.

Norman, D. J., Feng, L., Cheng, S. S., Gubbay, J., Chan, E., and Heintz, N. (1995). The lurcher gene induces apoptotic death in cerebellar Purkinje cells. Development 121, 1183-1193.

O’Gorman, S. (1985). Degeneration of thalamic neurons in "Purkinje cell degeneration" mutant mice. II. Cytology of neuron loss. J. Comp. Neurol. 234, 298-316.

Park, T. J., and Tom Curran, T. (2008). Crk and Crk-like play essential overlapping roles downstream of disabled-1 in the reelin pathway. J. Neurosci. 28, 13551-13562.

Phillips, R. J. S. (1960). "Lurcher", a new gene in linkage group XI of the house mouse. J. Genet. 57, 35-42.

Porras-García, E., Cendelin, J., Domínguez-del-Toro, E., Vozeh, F., and Delgado-García, J. M. (2005). Purkinje cell loss affects differentially the execution, acquisition and prepulse inhibition of skeletal and facial motor responses in Lurcher mice. Eur. J. Neurosci. 21, 979-988.

Porras-García, E., SánchezCampusano, R., Martínez-Vargas, D., Domínguez-del-Toro, E., Cendelín, J., Vozeh, F., et al. (2010). Behavioral characteristics, associative learning capabilities, and dynamic association mapping in an animal model of cerebellar degeneration. J. Neurophysiol. 104, 346-365.

Ramón y Cajal, S. (1911). Histologie du Système Nerveux de l'homme et des Vertébrés. Paris: Maloine.

Resibois, A., Cuvelier, L., and Goffinet, A. M. (1997). Abnormalities in the cerebellum and brainstem in homozygous lurcher mice. Neuroscience 80, 175-190.

Rossi, F., Jankovski, A., and Sotelo, C. (1995). Target neuron controls the integrity of afferent axon phenotype: a study on the Purkinje cell-climbing fiber system in cerebellar mutant mice. J. Neurosci. 15, 2040-2056.

Sánchez-Campusano, R., Gruart, A., and Delgado-García, J. M. (2007). The cerebellar interpositus nucleus and the dynamic control of learned motor responses. J. Neurosci. 27, 6620-6632.

Sánchez-Campusano, R., Gruart, A., and Delgado-García, J. M.
(2009). Dynamic associations in the cerebellar-motoneuron network during motor learning. J. Neurosci. 29, 10750-10763.

Schmidt, M. J., Sawyer, B. D., Perry, K. W., Fuller, R. W., Foreman, M. M., and Ghetti, B. (1982). Dopamine deficiency in weaver mutant mouse. J. Neurosci. 2, 376-380.

Sekiguchi, M., Nowakowski, R. S., Nagato, W., Tanaka, O., Guo, H., Madoka, M., et al. (1995). Morphological abnormalities in the hippocampus of weaver mutant mouse. Brain Res. 696, 262-267.

Sidman, R. L., and Green, M. M. (1970). "Nervous, a new mutant mouse with cerebellar disease," in Les Mutants Pathologiques chez l'Animal, ed M. Sabourdy (Paris: CNRS), 69-79.

Sidman, R. L., Lane, P., and Dickie, M. (1962). Staggerer, a new mutation in the mouse affecting the cerebellum. Science 137, 610-612.

Sotelo, C. (1980). Mutant mice and the formation of cerebellar circuitry. Trends Neurosci. 3, 33-36.

Sotelo, C., and Changeux, J. P. (1974a). Transsynaptic degeneration 'en cascade' in the cerebellar cortex of staggerer. Brain Res. 67, 519-526.

Sotelo, C., and Changeux, J. P. (1974b). Bergmann fibers and granule cell migration in the cerebellum of homozygous weaver mutant mouse. Brain Res. 77, 484-491.

Swisher, D. A., and Wilson, D. B. (1977). Cerebellar histogenesis in the Lurcher (Lc) mutant mouse. J. Comp. Neurol. 173, 205-217.

Takayama, C. (1994). Altered distribution of inhibitory synaptic terminals in reeler cerebellum with special reference to malposition of GABAergic neurons. Neurosci. Res. 20, 239-250.

Takayama, C., Nakagawa, S., Watanabe, M., Mishina, M., and Inoue, Y. (1995). Light- and electronmicroscopic localization of the glutamate receptor channel delta 2 subunit in the mouse Purkinje cell. Neurosci. Lett. 188, 89-92.

Takayama, C., Nakagawa, S., Watanabe, M., Mishina, M., and Inoue, Y. (1996). Developmental changes in expression and distribution of the glutamate receptor channel delta 2 subunit according to the Purkinje cell maturation. Brain Res. Dev. Brain Res. 92, 147-155.

Thach, W. T. (1997). Context-response linkage. Int. Rev. Neurobiol. 41, 599-611.
Thach, W. T., Googkin, H. P., and Keating, J. G. (1992). The cerebellum and the adaptative coordination of movement. Annu. Rev. Neurosci. 15, 403-442.

Triarhou, L. C., Norton, J., Alyea, C., and Ghetti, B. (1985). A quantitative study of the granule cells in Purkinje cell degeneration ( $p c d$ ) mutant. Ann. Neurol. 18, 146.

Triarhou, L. C., Norton, J., and Ghetti, B. (1987). Anterograde transsynaptic degeneration in the deep cerebellar nuclei of Purkinje cell degeneration (pcd) mutant mice. Exp. Brain Res. 66, 577-588.

Wassef, M., Sotelo, C., Cholley, B., Brehier, A., and Thomasset, M. (1987). Cerebellar mutations affecting the postnatal survival of Purkinje cells in the mouse disclose a longitudinal pattern of differentially sensitive cells. Dev. Biol. 124, 379-389.

Welsh, J. P., and Harvey, J. (1989). Cerebellar lesions and the nictitating membrane reflex: performance deficits of the conditioned and unconditioned response. J. Neurosci. 9, 299-311.

Wetts, R., and Herrup, K. (1982). Cerebellar Purkinje cells are descended from a small number of progenitors committed during early development: quantitative analysis of lurcher chimeric mice. J. Neurosci. 2, 1494-1498.

Wullner, U., Loschmann, P. A., Weller, M., and Klockgether, T. (1995) Apoptotic cell death in the cerebellum of mutant weaver and lurcher mice. Neurosci. Lett. 200, 109-112.

Yeo, C. H., Hardiman, M. J., and Glickstein, M. (1985a). Classical conditioning of the nictitating membrane response of the rabbit. I. Lesions of the cerebellar nuclei. Exp. Brain Res. 60, 87-98.

Yeo, C. H., Hardiman, M. J., and Glickstein, M. (1985b). Classical conditioning of the nictitating membrane response of the rabbit. II. Lesions of the cerebellar cortex. Exp. Brain Res. 60, 99-113.

Yi, S. S., Hwang, I. K., Shin, J. H., Baek, S. H., Yoon, Y. S., and Seong, J. K. (2010). Neuronal differentiation and developmental characteristics in the dentate gyrus of staggerer mutant mice. BMB Rep. 43,122-126.

Zanjani, H., Herrup, K., and Mariani, J. (2004). Cell number in the inferior olive of nervous and leaner mutant mice. J. Neurogenet. 18, 327-339. 
Zanjani, H. S., Mariani, J., and Herrup, K. (2007). Cell loss in the inferior olive of the staggerer mutant mouse is an indirect effect of the gene. J. Neurogenet. 21, 257-269.

Zuo, J., DeJager, P. L., Takahashi, K. A., Jiang, W., Linden, D. J., and Heintz, N. (1997). Neurodegeneration in Lurcher mice caused by mutation in d2 glutamate receptor. Nature 388, 769-773.

Conflict of Interest Statement: The authors declare that the research was conducted in the absence of any commercial or financial relationships that could be construed as a potential conflict of interest.
Received: 29 September 2012; paper pending published: 19 January 2013; accepted: 29 March 2013; published online: 23 April 2013.

Citation: Porras-García ME, Ruiz R, Pérez-Villegas EM and Armengol JÁ (2013) Motor learning of mice lacking cerebellar Purkinje cells. Front. Neuroanat. 7:4. doi: 10.3389/fnana. 2013.00004
Copyright (c) 2013 Porras-García, Ruiz, Pérez-Villegas and Armengol. This is an open-access article distributed under the terms of the Creative Commons Attribution License, which permits use, distribution and reproduction in other forums, provided the original authors and source are credited and subject to any copyright notices concerning any thirdparty graphics etc. 